\title{
A common variant of the $A B O$ gene protects against hypertension in a Spanish population
}

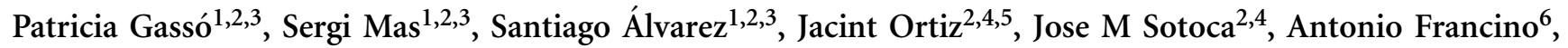
Xavier Carne ${ }^{1,2,7}$ and Amalia Lafuente ${ }^{1,2,7}$

The objective of this study was to establish whether genetic polymorphisms that could be related to angiotensin-converting enzyme (ACE) levels are associated with hypertension. A total of 10 haplotype-tagging single-nucleotide polymorphisms in $A C E$, the $A C E$ I/D polymorphism, and 2 polymorphisms in the $A B O$ (rs495828 and rs8176746) were investigated for association with hypertension in $\mathbf{2 6 9}$ hypertensive patients and 254 healthy controls. All analyses were adjusted for age and body mass index, and corrected for multiple testing. Only one polymorphism of the $A B O$ gene (rs495828) presented nominal pointwise $P<0.05$ values (odds ratio $=0.33,95 \% \mathrm{Cl} 0.19-0.58, P=6 \times 10^{-5}$ ) and achieved $P<3.8 \times 10^{-3}$, the nominal $P$-value considered significant after Bonferroni correction. Analysis of the genotype frequencies showed that the model that correctly explained the observed association was the recessive model (odds ratio $=0.03,95 \% \mathrm{Cl} 0.01-0.15, P=1 \times 10^{-6}$ ). These results indicate that genetic variants that could be related to ACE activity are good predictors of hypertension, and identify $A B O$ as a good candidate gene for genetic studies of hypertension risk. Further studies are required to confirm this association.
\end{abstract}

Hypertension Research (2012) 35, 592-596; doi:10.1038/hr.2011.218; published online 19 January 2012

Keywords: $\mathrm{ABO}$; angiotensin-converting enzyme; candidate gene association studies

\section{INTRODUCTION}

Hypertension has been considered a complex and polygenic trait. The risk of hypertension is known to be partially inherited, but although a high heritability has been described for blood pressure and hypertensive traits, no clearly reproducible genetic variants have been found for hypertension.

A large number of candidate genes have been tested for association with blood pressure and hypertensive traits without convincing results. ${ }^{1}$ Candidate genes have been selected from physiologically related systems implicated in blood pressure regulation, especially the renin-angiotensin system. ${ }^{2}$ The renin-angiotensin system is known to influence all aspects of blood pressure control, including blood vessel contraction, sodium balance and cell development in the heart. ${ }^{3}$ One of the most studied genes is that of the angiotensinconverting enzyme (ACE). Elevated ACE levels have been reported in patients with heart failure, ${ }^{4}$ and animal studies have demonstrated that the ACE gene is associated with blood pressure. ${ }^{5}$ Conflicting results have been published regarding the association of $A C E$ variants with hypertension, although two meta-analyses were unable to detect an independent association of the ACE I(insertion)/D(deletion) polymorphism with hypertension. ${ }^{6,7}$ This polymorphism, corresponding to a 287-base-pair insert in intron 16 of the gene, is associated with the ACE concentration in blood and tissues, subjects with one or two D alleles having $\sim 30$ and $60 \%$ higher ACE levels, respectively, than subjects with the II genotype. ${ }^{8}$ The ACE I/D polymorphism was originally proposed to account for $47 \%$ of the total phenotypic variance of circulating ACE. More recent investigations suggest that this percentage is much lower, possibly even close to $10 \% .^{9}$ Thus, it is now estimated that the I/D polymorphism accounts for $<20 \%$ of ACE variability. ${ }^{10}$ The role of other genetic variants in the ACE gene that may modulate ACE levels and activity cannot be excluded. Furthermore, recent genome-wide association studies (GWAS) for ACE enzyme activity found a strong association between one polymorphism in the ACE gene (rs4343) $\left(P=8.6 \times 10^{-21}\right)$ and two polymorphisms in the $A B O$ gene (rs495828 and rs8176746) $\left(P=2.5 \times 10^{-8}\right.$ and $\left.P=2.5 \times 10^{-6}\right)$ with increased activity in 400 Han Chinese; these associations were replicated in two independent cohorts. ${ }^{11}$ The rs4343 polymorphism is in high-moderate linkage disequilibrium (LD) with rs4305, a polymorphism of the ACE gene that has been related to the risk of hypertension $\left(P=3.0 \times 10^{-5}\right)$ in a study compromising 23 cohorts of three independent studies (Cohorts for Heart and Aging Research in Genomic Epidemiology Consortium; Global BPgen

${ }^{1}$ Department of Pathological Anatomy, Pharmacology and Microbiology, University of Barcelona, Barcelona, Spain; ${ }^{2}$ Institut d'Investigacions Biomèdiques August Pi i Sunyer (IDIBAPS), Barcelona, Spain; ${ }^{3}$ Centro de Investigación Biomédica en Red de Salud Mental (CIBERSAM), Barcelona, Spain; ${ }^{4}$ Primary Care Center Les Corts, Corporacio Sanitaria Clínic, Barcelona, Spain; ${ }^{5}$ Pharmacy Service, Hospital Clinic, Barcelona, Spain; ${ }^{6}$ Cardiology Department, Thorax Institute, Hospital Clinic, Barcelona, Spain; ${ }^{7}$ Clinical Pharmacology Service, Hospital Clinic, Barcelona, Spain

Correspondence: Dr A Lafuente, Department of Pathological Anatomy, Pharmacology and Microbiology, University of Barcelona, IDIBAPS, Casanova 143, E-08036 Barcelona, Spain.

E-mail: amalialafuente@ub.edu

Received 26 May 2011; revised 11 November 2011; accepted 24 November 2011; published online 19 January 2012 
Consortium; and Women's Genome Health Study) and a total of 86588 individuals. ${ }^{12}$ In a previous study, we associated the minor allele of the rs495828 polymorphism of the $A B O$ gene with the incidence of cough induced by treatment with ACE inhibitors in females $\left(P=6.0 \times 10^{-4}\right){ }^{13}$

According to the hypothesis that ACE activity could be an important marker of hypertension risk, our objective is the identification of genetic polymorphisms associated with hypertension risk that are related to this quantitative trait. As several polymorphisms in the ACE gene have been related to the level of ACE activity in different populations, we included a complete analysis of genetic variability of the ACE gene, using an extensive LD mapping approach with haplotype-tagging single-nucleotide polymorphisms (SNPs) selected from HapMap data for this gene. ${ }^{14}$ In addition, three polymorphisms that have been related to ACE levels were added to this selection: the $A C E$ I/D polymorphism (rs4340), ${ }^{8}$ and two polymorphisms in the $A B O$ gene (rs495828 and rs8176746). ${ }^{11}$

\section{METHODS}

\section{Subjects}

A cohort of 281 patients who had been treated with ACEi was retrospectively recruited at the Les Corts primary care center (Barcelona, Spain) and the Hospital Clínic (Barcelona, Spain). Of these, 12 cases were excluded as they presented concomitant diseases (coronary artery disease, heart failure, diabetes or chronic renal failure). A total of 269 patients with a diagnosis of hypertension participated in the present study. Hypertension was defined as a systolic blood pressure $\geqslant 140 \mathrm{~mm} \mathrm{Hg}$ and/or a diastolic blood pressure $\geqslant 90 \mathrm{~mm} \mathrm{Hg}$. The control group consisted of 373 subjects who were consecutively recruited at the Trauma Service of the Hospital Clínic and who had previously participated in genetic studies. ${ }^{15,16}$ Most of the controls were admitted for hip or knee joint replacement, pelvic fracture or injury to the upper or lower ribs. Of these, 254 individuals without a clinical history of hypertension, diabetes, cardiovascular or renal disease participated in the present study. A questionnaire was administered to each patient in an interview, which elicited demographic information, data on occupation and smoking habits, and personal medical history. The clinical information obtained was checked by examining clinical records.

All study participants were Caucasians who lived in Catalonia. Catalonia is a region in northeast Spain with 7210508 inhabitants, $96.2 \%$ of whom are Caucasian (http://www.idescat.cat/cat/idescat/publicacions/anuari/). Ethnicity was determined by self-reported ancestries: the cases and controls reported the ethnicity of each grandparent. We excluded subjects who mentioned nonEuropean grandparents. Written informed consent was obtained from each subject. The study was approved by the hospital's ethics committee.

\section{Sample preparation}

Blood samples were collected from the participating individuals in EDTA (K2EDTA BD Vacutainer EDTA tubes; Becton Dickinson, Franklin Lakes, NJ, USA) and genomic DNA was isolated using a DNA purification kit (Puregene; Gentra Systems, Indianapolis, IN, USA). The DNA concentration was determined by absorbance (ND1000, NanoDrop, Willmington, DE, USA).

\section{SNP selection, genotyping and quality control}

A total of 13 SNPs were selected from the $A C E$ gene region (covering target loci and regions $10-\mathrm{Kb}$ upstream and $10-\mathrm{Kb}$ downstream) by tagging analysis (as implemented in Haploview 4.1 (http://broad.mit.edu/mpg/haploview)) at an $r^{2}$ threshold of 0.8 . The aim was to capture $98 \%$ of the most common HapMap phase II variants, based on the CEU panel (minor allele frequency $>0.1$; Hardy-Weinberg equilibrium $P<0.05$; minimum genotyping rate $>85 \%$ ). One SNP was rejected before genotyping owing to the assay rules. The remaining 12 tag SNPs were genotyped using the MassARRAY genotyping system (Sequenom Inc., San Diego, CA, USA) at the Santiago de Compostela Node of the Spanish National Genotyping Center (CeGen). We excluded two SNPs whose genotypes were called in $<90 \%$ of samples or that had inconsistent clustering on inspection. The 10 validated SNPs tagged $90 \%$ of the most common HapMap II variants (minor allele frequency $>0.05$ ).
For quality control, eight samples were genotyped in duplicate for all the SNPs analyzed, with a concordance rate of $100 \%$.

Three SNPs were added to this selection: the ACE I/D polymorphism, which is the most common polymorphism in the ACE gene (rs4340), and two polymorphisms in the $A B O$ gene that have been related to ACE levels (rs495828 and rs8176746). The ACE I/D polymorphism was genotyped by conventional PCR, as described previously. ${ }^{17}$ The genotyping of rs495828 and rs8176746 was assessed using TaqMan ${ }^{\circledR}$ genotyping assays (Applied Biosystems, Foster City, CA, USA).

\section{Statistics}

Sample size and statistical power were calculated using Quanto1.2. software (http://hydra.usc.edu/gxe). Given the recruited sample size, and assuming a 5\% level of significance, we were able to detect odds ratio values of $>1.85$ with $>83 \%$ statistical power when polymorphisms with allele frequencies of $>0.1$ were analyzed. Data were analyzed using SPSS14.05 (statistical analysis software, SPSS Inc., Chicago, IL, USA). Means and s.d.'s were computed for continuous variables. Univariate analysis (the $\chi^{2}$ test for categorical variables and the Student $t$-test for continuous variables) was used to identify variables associated with elevated risk of hypertension. Three variables were considered: age, sex and body mass index (BMI). The analysis was adjusted for the variables that were significantly associated with increased risk of hypertension (age and $\mathrm{BMI}$ ). These variables were included in the logistic regression models used for the analysis. The best model was selected using the Akaike information criteria, using the SNPassoc $\mathrm{R}$ package. ${ }^{18}$ Hardy-Weinberg equilibrium and LD relationships between polymorphisms and haplotype block structures were evaluated using Haploview software v.3.2 (http://broad.mit.edu/mpg/haploview). For the haplotype estimations, we used a sliding windows approach in the haplo.stats $\mathrm{R}$ package. To avoid false-positive results caused by multiple testing, the Bonferroni correction was applied; given that 13 polymorphisms were analyzed, significant results were considered when $P<3.8 \times 10^{-3}$.

\section{RESULTS}

Table 1 summarizes the characteristics of the study population. The case group was older $\left(P=1 \times 10^{-6}\right)$ and had a higher BMI $\left(P=2 \times 10^{-7}\right)$ than the control group. The statistical analysis was adjusted to account for these factors. To avoid the possible confounding effect of these variables, we tested the possible associations of the genotypes included in the study with the clinical variables recorded. None of the polymorphisms tested showed significant associations with any of the variables considered.

The results of the allelic association analysis for single SNPs are shown in Table 2. All polymorphisms analyzed were in HardyWeinberg equilibrium. Only one polymorphism of the $A B O$ gene (rs495828) presented nominal pointwise $P<0.05$ values (odds ratio $=0.33,95 \%$ CI $\left.0.19-0.58, \quad P=6 \times 10^{-5}\right)$ and achieved $P<3.8 \times 10^{-3}$, the nominal $P$-value considered significant after Bonferroni correction. Analysis of the genotype frequencies under codominant, dominant, overdominant, recessive and additive models revealed that the model that correctly explained the observed association of rs495828 was the recessive model $\left(P=1 \times 10^{-6}\right)$ (Table 3).

None of the haplotypes constructed in the ACE gene were significantly associated with hypertension, not even the haplotype blocks that included SNPs that were significantly associated with this disease in the literature (ACE I/D, rs4305, rs4343).

\section{DISCUSSION}

The aim of the present study was to evaluate the possible association between genetic variability and candidate polymorphisms in genes related to ACE levels ( $A C E$ and $A B O$ ), and the risk of hypertension. This is the first time that the $A B O$ gene has been linked with hypertension. This genetic study revealed an association between hypertension and a genetic polymorphism in the $A B O$ gene. These 
results are consistent with the proposed role of this gene in ACE activity. $^{11}$

ACE activity represents an upstream and internal facet of hypertension, and has reasonably high heritability ${ }^{19}$ and low intra-individual variation. ${ }^{20}$ It could be considered a 'good intermediate phenotype' or endophenotype for predicting risk of hypertension. ${ }^{11,21}$ Recently, a genome-wide analysis of the quantitative trait of ACE identified three polymorphisms as good predictors of ACE activity: rs4343 (ACE), rs495828 and rs8176746 (ABO). ${ }^{11}$ We included these three polymorphisms in our study and found a strong association between rs495828 and hypertension. In our population, carriers of the T allele, who have lower ACE levels according to Chung et al., ${ }^{11}$ had a lower risk of developing hypertension.

$A B O$ encodes glycosyltransferases, which transfer monosaccharides to the cell-surface $\mathrm{H}$ antigens. As ACE molecules are carriers of $\mathrm{ABO}$ antigens, oligosaccharide moieties on $\mathrm{ABO}$ antigens that are bound covalently to the ACE molecules may affect the aqueous solubility of ACE and its susceptibility to proteases, resulting in the release of varying amounts of active enzyme. The association of the $\mathrm{ABO}$ blood group system with hypertension is not a new idea. Cidl et al. ${ }^{22}$ found an independent effect of the ABO blood group on ACE serum activity. The different glycosylation of the ACE molecule in different ABO blood groups seems to modulate the regulation of blood pressure in a given subject depending on the genetic variants of glycosylated genes. Moreover, Vasku et al. ${ }^{23}$ identified an association of blood pressure with ACE I/D polymorphism and ABO blood group. The differences in the distribution of these $\mathrm{ABO}$ groups among ethnicities

Table 1 Characteristics of the study population

\begin{tabular}{|c|c|c|c|}
\hline & Controls $(n=254)$ & Cases $(n=269)$ & P-value \\
\hline Females (\%) & 55.5 & 52.8 & 0.264 \\
\hline Age (years) & $61.7 \pm 21$ & $70.4 \pm 1$ & $1 \times 10^{-6}$ \\
\hline $\mathrm{BMI}\left(\mathrm{kg} \mathrm{m}^{-2}\right)$ & $25.6 \pm 2.5$ & $28.6 \pm 1.8$ & $2 \times 10^{-7}$ \\
\hline $\mathrm{SBP}(\mathrm{mm} \mathrm{Hg})$ & - & $143.1 \pm 6.4$ & - \\
\hline DBP $(\mathrm{mm} \mathrm{Hg})$ & - & $80.5 \pm 5.2$ & - \\
\hline
\end{tabular}

Abbreviations: BMI, body mass index; DBP diastolic blood pressure; SBP, systolic blood pressure.

${ }^{a} \chi^{2}$ test for categorical variables and the Student $t$-test for continuous variables. could explain the ethnic differences observed in the incidence of hypertension.

We found no significant associations with rs4343, the ACE polymorphism proposed to explain the highest percentage of ACE activity in a Han Chinese population. ${ }^{11}$ It does not introduce any change into the amino-acid sequence of the ACE protein. Given that this is a synonymous SNP, and the existing differences in LD relationships among SNPs across different populations, we cannot rule out the possibility that rs 4343 could be a marker polymorphism rather than a causal variant. rs4305 (Hapmap Caucasian population $D^{\prime}=0.86$ ) may mark the same functional variant.

In our study, no association with hypertension was observed for the $A C E \mathrm{I} / \mathrm{D}$ polymorphism although it has been linked with hypertension $^{24-28}$ and ACE levels. ${ }^{8,20,29}$ However, after being a focus of research

Table 3 Genotype association study of rs 495828 adjusted by age and BMI, analyzed under codominant, dominant, overdominant and recessive models

\begin{tabular}{|c|c|c|c|c|c|c|}
\hline & Controls $n(\%)$ & Cases n (\%) & $O R$ & $95 \% \mathrm{Cl}$ & $\mathrm{P}$-value & $A / C$ \\
\hline \multicolumn{7}{|l|}{ Codominant } \\
\hline $\mathrm{G} / \mathrm{G}$ & $138(54.3)$ & $175(65.0)$ & 1.00 & & $4.1 \times 10^{-6}$ & 608.3 \\
\hline $\mathrm{G} / \mathrm{T}$ & $92(36.2)$ & 88 (32.7) & 0.65 & $0.32-1.33$ & & \\
\hline $\mathrm{T} / \mathrm{T}$ & $24(9.4)$ & $6(2.2)$ & 0.03 & $0.01-0.13$ & & \\
\hline \multicolumn{7}{|l|}{ Dominant } \\
\hline $\mathrm{G} / \mathrm{G}$ & $138(54.3)$ & $175(65.0)$ & 1.00 & & 0.01 & 624.5 \\
\hline $\mathrm{G} / \mathrm{T}-\mathrm{T} / \mathrm{T}$ & $116(45.7)$ & 94 (34.9) & 0.42 & $0.22-0.83$ & & \\
\hline \multicolumn{7}{|l|}{ Recessive } \\
\hline $\mathrm{G} / \mathrm{G}-\mathrm{G} / \mathrm{T}$ & $230(90.6)$ & $263(97.7)$ & 1.00 & & $1.3 \times 10^{-6}$ & 607.7 \\
\hline $\mathrm{T} / \mathrm{T}$ & $24(9.4)$ & $6(2.2)$ & 0.03 & $0.01-0.15$ & & \\
\hline \multicolumn{7}{|c|}{ Overdominant } \\
\hline G/G-T/T & $162(63.8)$ & $181(67.3)$ & 1.00 & & 0.8 & 631.1 \\
\hline $\mathrm{G} / \mathrm{T}$ & $92(36.2)$ & $88(32.7)$ & 0.93 & $0.47-1.81$ & & \\
\hline
\end{tabular}

Abbreviations: AIC, Akaike information criterion; BMI, body mass index; OR, odds ratio; $95 \% \mathrm{Cl}$, $95 \%$ confidence interval. In bold the best model according to the Akaike information criteria (AIC).

Table 2 Allelic association study adjusted by age and BMI

\begin{tabular}{|c|c|c|c|c|c|c|c|}
\hline Gene & Name & Position ${ }^{\mathrm{a}}$ & Hardy-Weinberg & Alleles ${ }^{c}$ & Controls frequency & Cases frequency & P-value ${ }^{d}$ \\
\hline$A C E$ & rs35865660 & 58913765 & 1.0 & C:T & 0.002 & 0.004 & 0.6043 \\
\hline$A C E$ & rs28730839 & 58914233 & - & $\mathrm{C}: \mathbf{G}$ & 1.000 & 1.000 & - \\
\hline$A C E$ & rs4316 & 58916041 & 0.89 & C:T & 0.387 & 0.387 & 0.9924 \\
\hline$A C E$ & rs4340 & 58919624 & 0.98 & $C: A$ & 0.392 & 0.389 & 0.9209 \\
\hline$A C E$ & rs4343 & 58919763 & 1.0 & $\mathrm{G}: \mathrm{A}$ & 0.402 & 0.407 & 0.8872 \\
\hline$A C E$ & rs4357 & 58925362 & 1.0 & $C: T$ & 0.002 & 0.007 & 0.2063 \\
\hline$A C E$ & rs12720737 & 58925568 & 1.0 & C:T & 0.002 & 0.002 & 0.9586 \\
\hline$A C E$ & rs4363 & 58928224 & 0.65 & G.A & 0.396 & 0.396 & 0.9656 \\
\hline$A C E$ & rs4461142 & 58931780 & 0.45 & $\mathrm{~T}: \mathbf{C}$ & 0.446 & 0.442 & 0.9465 \\
\hline$A C E$ & rs4267385 & 58937488 & 0.15 & $\mathrm{~T}: \mathrm{C}$ & 0.395 & 0.355 & 0.1844 \\
\hline$A C E$ & rs4459610 & 58938452 & 0.16 & $\mathrm{~T}: \mathbf{A}$ & 0.392 & 0.354 & 0.2064 \\
\hline$A B O$ & rs8176746 & 135121143 & 0.10 & G:T & 0.072 & 0.058 & 0.3626 \\
\hline$A B O$ & rs495828 & 135144688 & 0.62 & $\mathrm{G}: \mathrm{T}$ & 0.273 & 0.184 & $6 \times 10^{-5}$ \\
\hline
\end{tabular}

Abbreviation: BMI, body mass index.

aposition according to NCBI sequence viewer genome build 36.3.

${ }^{\mathrm{b}} P$-value of the Hardy-Weinberg equilibrium in the control group.

In bold: associated allele.

din bold: significant nominal $P$-values $\left(P<3.8 \times 10^{-3}\right)$. 
for more than two decades, the clinical significance of the $A C E \mathrm{I} / \mathrm{D}$ has yet to be established. ${ }^{30}$

Our results highlight the importance of genetic determinants of ACE levels as good predictors of hypertension, and identify $A B O$ as a good candidate gene for genetic studies of hypertension risk. This gene has not been linked with hypertension previously, either in the candidate gene approach or in GWAS. To date, 13 GWAS on blood pressure and hypertension have been published, including studies whose main objective was not blood pressure genetics. ${ }^{31}$ Only 1 SNP reached genome-wide significance for hypertension in a primary GWAS meta-analysis, whereas in the same study 10 SNPs reached this threshold for systolic or diastolic blood pressure. ${ }^{32}$ It is possible that the differences in the number of significant findings are due to differences in power; continuous traits have greater power than discrete traits, and therefore the chances of obtaining a significant result are higher with continuous traits. Indeed, many factors contribute to the inter- and intra-individual variability in blood pressure. Some have correctly argued that blood pressure in genomic studies is suboptimal because it is generally limited to a few measurements at a given point in time. ${ }^{33}$ In total, 14 independent loci have been identified for blood pressure traits that reached genome-wide significance, including replication in independent cohorts. ${ }^{32,34,35}$ These 14 loci are in or near genes encoding six enzymes (including three kinases and one cytochrome), two solute channels, two transcription factors, one growth factor, one cell signaling protein, one structural protein and one hypothetical gene. Of these genes, only 2 out of 14 (CYP17A1 and MTHFR) would have been identified as a blood pressure candidate gene before these studies. All of the other genes closest to the variants identified were previously largely unsuspected for involvement in blood pressure regulation.

Our study is not free of shortcomings. First, the sample size used in the present study is much smaller than those presented in the largest cohorts for the study of hypertension; however, we had enough statistical power to detect the significant associations described here. Given our sample size, polymorphisms were selected with allelic frequencies $>10 \%$ to achieve the desired statistical power. Second, cases were recruited to participate in a pharmacogenetic study of ACE inhibitors. ${ }^{13}$ For this reason, all cases were being treated with this antihypertensive drug. Thus, our group of cases could represent a clinical subgroup of the disease. Although this provided us with a more homogenous sample, our significant associations may not be predictive in the overall group of hypertension patients. Moreover, taking into account the BMI value in our group of cases, it may be that our cohort represents overweight hypertensive patients who may not be representative of overall hypertensive patients. Third, our groups of cases and controls differed in terms of age and BMI, two risk factors for hypertension. However, to avoid any confounding effect of these variables, both age and BMI were included as covariables in the statistical analysis. We are aware that other risk factors exist for hypertension, including diabetes, sex, dyslipidemia, smoking and alcohol intake. ${ }^{35,36}$ In our study, the cases and controls had a similar sex distribution, and none of the participant had a diagnosis of diabetes, as it was an exclusion criteria in both. For these reasons no adjustment is needed for these variables. However, we have no data for other risk factors such as dyslipidemia, smoking or alcohol intake. Our results could be biased owing to these risk factors, and we cannot rule out the possibility that our significant results are associated with these variables rather than the genetic risk of hypertension. Finally, although we assume that most of the patients participating in this study presented essential hypertension, we cannot role out the possible existence of secondary hypertension in some cases. For this reason, our cohort may contain a mixed phenotype of essential and secondary hypertension.

In conclusion, our study showed the influence of the $A B O$ gene on hypertension. These results indicate that genetic variants that could be related to ACE activity are good predictors of hypertension. Further studies are required to confirm this association. If confirmed, it should be included in clinical practice as a possible risk factor for hypertension.

\section{ACKNOWLEDGEMENTS}

PG was supported by a 'Sara Borrell' contract (CD09/00296) from the Spanish Ministry of Health, Instituto de Salud Carlos III (FIS, Fondo de Investigacion Sanitaria). This study was supported by the Spanish Ministry of Health, Instituto de Salud Carlos III (FIS, Fondo de Investigacion Sanitaria EC090239) and the Catalonia Ministry of Innovation, Universities and Enterprise (DIUE, 2009SGR1501). The authors thank Belen de Pedro and Meritxell Devant for their assistance in patient recruitment, and the Language Advisory Service at the University of Barcelona for manuscript revision.

1 Binder A. A review of the genetics of essential hypertension. Curr Opin Cardiol 2007; 22: 176-184.

2 Gong M, Hubner N. Molecular genetics of human hypertension. Clin Sci (Lond) 2006; 110: 315-326.

3 Perazella MA, Setaro JF. Renin-angiotensin-aldosterone system: fundamental aspects and clinical implications in renal and cardiovascular disorders. J Nucl Cardiol 2003; 10: $184-196$.

4 Studer R, Reinecke H, Müller B, Holtz J, Just H, Drexler H. Increased angiotensin-I converting enzyme gene expression in the failing human heart. Quantification by competitive RNA polymerase chain reaction. J Clin Invest 1994; 94: 301-310.

5 Esther Jr CR, Howard TE, Zhou Y, Capecchi MR, Marrero MB, Bernstein KE. Lessons from angiotensin-converting enzyme-deficient mice. Curr Opin Nephrol Hypertens 1996; 5: 463-467.

6 Staessen JA, Ginocchio G, Wang JG, Saavedra AP, Soubrier F, Vlietinck R, Fagard R. Genetic variability in the renin-angiotensin system: prevalence of alleles and genotypes. J Cardiovasc Risk 1997; 4: 401-422.

7 Agerholm-Larsen B, Nordestgaard BG, Tybjaerg-Hansen A. ACE gene polymorphism in cardiovascular disease: meta-analyses of small and large studies in whites. Arterioscler Thromb Vasc Biol 2000; 20: 484-492.

8 Rigat B, Hubert C, Alhenc-Gelas F, Cambien F, Corvol P, Soubrier F. An insertion/ deletion polymorphism in the angiotensin I-converting enzyme gene accounting for half the variance of serum enzyme levels. J Clin Invest 1990; 86: 1343-1346.

9 Rice GI, Jones AL, Grant PJ, Carter AM, Turner AJ, Hooper NM. Circulating activities of angiotensin-converting enzyme, its homolog, angiotensin-converting enzyme 2 , and neprilysin in a family study. Hypertension 2006; 48: 914-920.

10 Danser AH, Batenburg WW, van den Meiracker AH, Danilov SM. ACE phenotyping as a first step toward personalized medicine for ACE inhibitors. Why does ACE genotyping not predict the therapeutic efficacy of ACE inhibition? Pharmacol Ther 2007; 113 . 607-618.

11 Chung CM, Wang RY, Chen JW, Fann CS, Leu HB, Ho HY, Ting CT, Lin TH, Sheu SH, Tsai WC, Chen JH, Jong YS, Lin SJ, Chen YT, Pan WH. A genome-wide association study identifies new loci for ACE activity: potential implications for response to ACE inhibitor. Pharmacogenomics J 2010; 10: 537-544.

12 Johnson AD, Newton-Cheh C, Chasman DI, Ehret GB, Johnson T, Rose L, Rice K, Verwoert GC, Launer LJ, Gudnason V, Larson MG, Chakravarti A, Psaty BM, Caulfield M, van Duijn CM, Ridker PM, Munroe PB, Levy D. Association of hypertension drug target genes with blood pressure and hypertension in 86588 individuals. Hypertension 2011; 57: 903-910.

13 Mas S, Gassó P, Ivarez S, Ortiz J, Sotoca JM, Francino A, Carne X, Lafuente A. Pharmacogenetic predictors of angiotensin-converting enzyme inhibitor induced cough; the role of ACE, ABO and BDKRB2 genes. Pharmacogenet Genom 2011; 21: 531-538.

14 Gunderson KL, Kuhn KM, Steeners FJ, Ng P, Murray SS, Shen R. Whole genome genotyping of haplotype tag single nucleotide polymorphisms. Pharmacogenomics $J$ 2006; 7: 641-648.

15 Lafuente MJ, Casterad X, Trias M, Ascaso C, Molina R, Ballesta A, Zheng S, Wiencke JK, Lafuente A. Oxidoreductase-dependent risk for colorectal cancer and its association with the presence of K-ras mutations in tumors. Carcinogenesis 2000; 21: 1813-1819.

16 Mas S, Bernardo M, Gassó P, Alvarez S, Garcia-Rizo C, Bioque M, Kirkpatrick B, Lafuente A. A functional variant provided further evidence for the association of ARVCF with schizophrenia. Am J Med Genet B Neuropsychiatr Genet 2010; 153B: 1052-1059.

17 Crescenti A, Gassó P, Mas S, Abellana R, Delofeu R, Parellada E, Bernardo M, Lafuente A. Ins/del polymorphism of the angiotensin-converting-enzyme (ACE) gene is 
associated with schizophrenia in a Spanish population. Psychiatry Res 2009; 165 : $175-180$.

18 González JR, Armengol L, Sol X, Guinó E, Mercader JM, Estivill X, Moreno V. SNPassoc: an $\mathrm{R}$ package to perform whole genome association studies. Bioinformatics 2007; 23 : 644-645.

19 Zhu X, Bouzekri N, Southam L, Cooper RS, Adeyemo A, McKenzie CA, Luke A, Chen G, Elston RC, Ward R. Linkage and association analysis of angiotensin I-converting enzyme (ACE)-gene polymorphisms with ACE concentration and blood pressure. Am J Hum Genet 2001; 68: 1139-1148.

20 Alhenc-Gelas F, Richard J, Courbon D, Warnet JM, Corvol P. Distribution of plasma angiotensin I-converting enzyme levels in healthy men: relationship to environmental and hormonal parameters. J Lab Clin Med 1991; 117: 33-39.

21 Jan Danser AH, Batenburg WW, van Esch JH. Prorenin and the (pro)renin receptor-an update. Nephrol Dial Transplant 2007; 22: 1288-1292.

22 Cídl K, Strelcov L, Znojil V, Váchi J. Angiotensin I-converting enzyme (ACE) polymorphism and ABO blood groups as factors codetermining plasma ACE activity. Exp Hematol 1996; 24: 790-794.

23 Vasku A, Soucek M, Hajek D, Holla V, Znojil V, Vacha I. Association analysis of 24-h blood pressure records with I/D ACE gene polymorphism and ABO blood group system. Physiol Res 1999; 48: 99-104.

24 Kato N, Tatara Y, Ohishi M, Takeya Y, Onishi M, Maekawa Y, Rakugi H. Angiotensinconverting enzyme single nucleotide polymorphism is a genetic risk factor for cardiovascular disease: a cohort study of hypertensive patients. Hypertens Res 2011; 34: $728-734$.

$25 \mathrm{Ji}$ LD, Zhang LN, Shen P, Wang P, Zhang YM, Xing WH, Xu J. Association of angiotensinogen gene M235T and angiotensin-converting enzyme gene I/D polymorphisms with essential hypertension in Han Chinese population: a meta-analysis. J Hypertens 2010; 28: 419-428.

26 Tascilar N, Dursun A, Ankarali H, Mungan G, Ekem S, Baris S. Angiotensin-converting enzyme insertion/deletion polymorphism has no effect on the risk of atherosclerotic stroke or hypertension. J Neurol Sci 2009; 285: 137-141.

27 Niu W, Qi Y, Hou S, Zhai X, Zhou W, Qu C. Haplotype-based association of the renin-angiotensin-aldosterone system genes polymorphisms with essential hypertension among Han Chinese: the Fangshan study. J Hypertens 2009; 27: 1384-1391.

28 Das M, Pal S, Ghosh A. Angiotensin converting enzyme gene polymorphism (insertion/ deletion) and hypertension in adult Asian Indians: a population-based study from Calcutta, India. Hum Biol 2008; 80: 303-312.

29 Tiret L, Rigat B, Visvikis S, Breda C, Corvol P, Cambien F, Soubrier F. Evidence, from combined segregation and linkage analysis, that a variant of the angiotensin Iconverting enzyme (ACE) gene controls plasma ACE levels. Am J Hum Genet 1992; 51: 197-205.

30 de Denus S. Pharmacogenomic testing for angiotensin-converting enzyme inhibitors: getting ready for prime time. Pharmacogenomics 2010; 11: 1345-1348.
31 Ehret GB. Genome-wide association studies: contribution of genomics to understanding blood pressure and essential hypertension. Curr Hypertens Rep 2010; 2: 17-25.

32 Levy D, Ehret GB, Rice K, Verwoert GC, Launer LJ, Dehghan A, Glazer NL, Morrison AC, Johnson AD, Aspelund T, Aulchenko Y, Lumley T, Köttgen A, Vasan RS, Rivadeneira F, Eiriksdottir G, Guo X, Arking DE, Mitchell GF, Mattace-Raso FU, Smith AV, Taylor K, Scharpf RB, Hwang SJ, Sijbrands EJ, Bis J, Harris TB, Ganesh SK, O'Donnell CJ, Hofman A, Rotter JI, Coresh J, Benjamin EJ, Uitterlinden AG, Heiss G, Fox CS, Witteman JC, Boerwinkle E, Wang TJ, Gudnason V, Larson MG, Chakravarti A, Psaty $\mathrm{BM}$, van Duijn CM. Genome-wide association study of blood pressure and hypertension. Nat Genet 2009; 41: 677-687.

33 Franks PW. Identifying genes for primary hypertension: methodological limitations and gene-environment interactions. J Hum Hypertens 2009; 23: 227-237.

34 Newton-Cheh C, Johnson T, Gateva V, Tobin MD, Bochud M, Coin L, Najjar SS, Zhao JH, Heath SC, Eyheramendy S, Papadakis K, Voight BF, Scott LJ, Zhang F, Farrall M, Tanaka T, Wallace C, Chambers JC, Khaw KT, Nilsson P, van der Harst P, Polidoro S, Grobbee DE, Onland-Moret NC, Bots ML, Wain LV, Elliott KS, Teumer A, Luan J, Lucas G, Kuusisto J, Burton PR, Hadley D, McArdle WL, Brown M, Dominiczak A, Newhouse SJ, Samani NJ, Webster J, Zeggini E, Beckmann JS, Bergmann S, Lim N, Song K, Vollenweider P, Waeber G, Waterworth DM, Yuan X, Groop L, Orho-Melander M, Allione A, Di Gregorio A, Guarrera S, Panico S, Ricceri F, Romanazzi V, Sacerdote C, Vineis P, Barroso I, Sandhu MS, Luben RN, Crawford GJ, Jousilahti P, Perola M, Boehnke M, Bonnycastle LL, Collins FS, Jackson AU, Mohlke KL, Stringham HM, Valle TT, Willer CJ, Bergman RN, Morken MA, Döring A, Gieger C, Illig T, Meitinger T, Org E, Pfeufer A, Wichmann HE, Kathiresan S, Marrugat J, O'Donnell CJ, Schwartz SM, Siscovick DS, Subirana I, Freimer NB, Hartikainen AL, McCarthy MI, O'Reilly PF, Peltonen L, Pouta A, de Jong PE, Snieder H, van Gilst WH, Clarke R, Goel A, Hamsten A, Peden JF, Seedorf U, Syvänen AC, Tognoni G, Lakatta EG, Sanna S, Scheet P, Schlessinger D, Scuteri A, Dörr M, Ernst F, Felix SB, Homuth G, Lorbeer R, Reffelmann T, Rettig R, Völker U, Galan P, Gut IG, Hercberg S, Lathrop GM, Zelenika D, Deloukas P, Soranzo N, Williams FM, Zhai G, Salomaa V, Laakso M, Elosua R, Forouhi NG, Völzke H, Uiterwaal CS, van der Schouw YT, Numans ME, Matullo G, Navis G, Berglund G, Bingham SA, Kooner JS, Connell JM, Bandinelli S, Ferrucci L, Watkins H, Spector TD, Tuomilehto J, Altshuler D, Strachan DP, Laan M, Meneton P, Wareham NJ, Uda M, Jarvelin MR, Mooser V, Melander O, Loos RJ, Elliott P, Abecasis GR, Caulfield M, Munroe PB. Genome-wide association study identifies eight loci associated with blood pressure. Nat Genet 2009; 41: 666-676.

35 Wang Y, O'Connell JR, McArdle PF, Wade JB, Dorff SE, Shah SJ, Shi X, Pan L, Rampersaud E, Shen H, Kim JD, Subramanya AR, Steinle NI, Parsa A, Ober CC, Welling PA, Chakravarti A, Weder AB, Cooper RS, Mitchell BD, Shuldiner AR, Chang YP. From the cover: whole-genome association study identifies STK39 as a hypertension susceptibility gene. Proc Natl Acad Sci USA 2009; 106: 226-231.

36 de Simone G, Devereux RB, Chinali M, Roman MJ, Best LG, Welty TK, Lee ET, Howard BV. Risk factors for arterial hypertension in adults with initial optimal blood pressure: The Strong Heart Study. Hypertension 2006; 47: 162-167. 